\title{
Allergen-induced cytokine secretion in atopic and non-atopic asthmatic children
}

Malin Böttcher, Jenny Bjurström, Xiaomei Mai, Lennart Nilsson and Maria Jenmalm

\author{
Linköping University Post Print
}

\section{Tweet}

N.B.: When citing this work, cite the original article.

This is the pre-reviewed version of the following article:

Malin Böttcher, Jenny Bjurström, Xiaomei Mai, Lennart Nilsson and Maria Jenmalm, Allergen-induced cytokine secretion in atopic and non-atopic asthmatic children, 2003, Pediatric Allergy and Immunology, (14), 5, 345-350.

which has been published in final form at:

http://dx.doi.org/10.1034/j.1399-3038.2003.00061.x

Copyright: Wiley-Blackwell http://eu.wiley.com/WileyCDA/Brand/id-35.html

Postprint available at: Linköping University Electronic Press http://urn.kb.se/resolve?urn=urn:nbn:se:liu:diva-26399 


\title{
Allergen induced cytokine secretion in
}

\section{atopic and non-atopic asthmatic children}

\author{
Malin F Böttcher \\ Jenny Bjurström \\ Xiao-Mei Mai \\ Lennart Nilsson \\ Maria C Jenmalm
}
Department of Molecular and Clinical Medicine, Division of Paediatrics, and Clinical Research Centre, Faculty of Health Sciences, Linköping University, Sweden

Running title: Allergen induced cytokines in asthmatic children 
Titel: Allergen induced cytokine secretion in atopic and non-atopic asthmatic children

Journal: Pediatr Allergy Immunol

\section{Abstract}

Background: Atopic asthma is characterised by excessive T helper 2 (Th2)-like immunity to allergens in the bronchial mucosa. The Th2-cytokine interleukin (IL)-4 induces IgE production, while the Th2-cytokine IL-5 promotes eosinophilic inflammation in the airways of asthmatics. Most asthmatics are atopic, but a sub-group is non-atopic. We hypothesise that allergen induced Th2-, particularly IL-5, responses, can be observed in peripheral blood in both atopic and non-atopic asthmatic children but not in healthy control children.

Aim: To determine IL-4, IL-5, IL-9, IL-10, IL-13 and IFN- $\gamma$ secretion induced from PBMC by a broad panel of inhalant allergens (timothy, cat, birch, dog and house dust mite) in asthmatic children with and without sensitisation.

Materials and methods: The study included 13 atopic asthmatic, 5 non-atopic asthmatic, and 12 non-atopic non-asthmatic children. PBMC were stimulated with allergens and cytokine production was measured with ELISA.

Results: High levels of cat and dog induced IL-5 were more commonly observed in both atopic and non-atopic asthmatics than in controls. Children with atopic, but not non-atopic, asthma produced higher levels of allergen induced IL-4 and IL-9 than controls. Non-atopic asthmatics produced more IL-10 than atopic asthmatics after cat stimulation. 
Conclusion: High levels of eosinophilia-associated IL-5 responses are induced by cat and dog allergen in both atopic and non-atopic asthmatic children. The Th2 cytokines IL-4 and IL-9 were associated only with atopic asthma, probably due to their IgE-inducing properties.

Keywords: asthma, atopy, allergen, childhood, cytokines, Th2

Correspondence to: Malin F Böttcher

KFC/Div Paediatrics

Linköping University Hospital

S-581 85 Linköping

Sweden

Tel +46-13-223565

Fax +46-13-127465

e-mail MalFa@kfc.liu.se 


\section{Abbreviations}

ELISA enzyme-linked immunosorbent assay

HDM house dust mite

IFN interferon

Ig immunoglobulin

IL interleukin

ISAAC international study of asthma and allergies in childhood

OD optical densities

PBMC peripheral blood mononuclear cells

PBS phosphate buffered saline

PHA phytohaemagglutinin A

SPT skin prick test

Th T helper 


\section{Introduction}

Atopic asthma is characterised by excessive T helper 2 (Th2)-like immunity to allergens in the bronchial mucosa [1], circulating specific immunoglobulin E (IgE) antibodies, positive skin prick tests (SPT) to common aeroallergens, and airway hyperresponsiveness [2]. Th2 cells produce immunoglobulin E (IgE) synthesis promoting interleukin-4 (IL-4) [3] and IL-13 [4], eosinophilia promoting IL-5 and IL-9 [5, 6], while interferon- $\gamma$ (IFN- $\gamma$ ) from Th1 cells downregulate IgE synthesis [3]. Interleukin-9 also enhances IgE production [7] and stimulates $\mathrm{T}$ cell and mast cell growth $[8,9]$. Interleukin-10 is an antiinflammatory cytokine [10], that inhibits both Th1 and Th2 cells and IgE synthesis [11], as well as shortens eosinophil survival [10].

The immunological mechanisms occurring in the subgroup of patients with intrinsic (non-atopic) asthma, where no sensitisation can be demonstrated, are less well characterised, particularly in children. In a series of bronchial biopsy studies of asthmatic adults, both atopic and non-atopic asthma were characterised by infiltration of eosinophils, and expression of IL-4 and IL-5, eosinophil chemotactic cytokines and receptors [12-14]. It has been suggested that non-atopic asthmatics are allergic to an as yet undetected allergen or that IgE production in non-atopic asthmatics is local rather than generalized [14]. It is possible that allergen specific Th2 cells have been activated and perform their effector functions locally in the lung. Those T cells may then be identified in the circulation of non-atopic asthmatics. If allergens induce inflammation also in 
the lungs of non-atopic asthmatics, these patients could benefit from immunotherapy and allergen avoidance [14].

Others have found that IL-5 protein levels in bronchoalveolar lavage are elevated both in atopic and non-atopic asthmatic adults, as compared to controls, whereas IL-4 is detected only in atopic asthmatics [15]. As IL-4 and IL5 are differentially regulated [16-18], eosinophil mediated inflammation in the absence of IgE may be possible. We hypothesised that high levels of allergen induced Th2-, particularly IL-5, responses can be observed in peripheral blood of asthmatic children, independent of sensitisation, but not in healthy children.

The aim of this study was to determine IL-4, IL-5, IL-9, IL-10, IL-13 and IFN- $\gamma$ secretion induced from peripheral blood mononuclear cells (PBMC) by a broad panel of inhalant allergens (timothy, cat, birch, dog, and house dust mite) in atopic and non-atopic asthmatic children. 


\section{Materials and methods}

\section{Subjects}

The study included 30 children, aged 13-15-years, identified from phase 2 of the Linköping part of the International Study of Asthma and Allergies in Childhood (ISAAC). Atopic symptoms were determined by the ISAAC phase 2 questionnaire. Asthma was defined as bronchial obstruction $\geq$ four times/year and a positive bronchial provocation test. Based on these criteria, 18 children were defined as asthmatics. To perform the bronchial provocation test, the baseline and post-challenge $\mathrm{FEV}_{1}$ were recorded using a MasterScope spirometer (JAEGER, Hoechberg, Germany), as described in [19]. Briefly, at least two baseline spirograms were performed and the highest of two reproducible (within 5\%) measures of $\mathrm{FEV}_{1}$ was recorded as the baseline $\mathrm{FEV}_{1}$. The children then inhaled hyperosmolar saline $(4.5 \%)$. The time of inhalation was progressively increased, starting with 30 seconds and with a maximum total inhalation period of 15.5 minutes. After every inhalation, $\mathrm{FEV}_{1}$ was measured and the fall in $\mathrm{FEV}_{1}$ was calculated. The challenge test was stopped and considered to be positive, when the decline in $\mathrm{FEV}_{1}$ was more than $15 \%$.

At the time of blood sampling, skin prick tests (SPT) were performed in duplicate on the volar aspects of the forearms with standardised birch, timothy, cat, dog and house dust mite (Dermatophagoides pteronyssinus and Dermatophagoides farinae) extracts (Soluprick ${ }^{\circledR}$, strength 10 histamine equivalents in prick testing for all allergens, ALK, Hørsholm, Denmark). 
Histamine hydrochloride $(10 \mathrm{mg} / \mathrm{ml})$ was used as a positive control and albumin diluent as negative control. The test was regarded as positive when the mean diameter was $\geq 3 \mathrm{~mm}$. Thirteen of the asthmatic children were SPT positive to at least two allergens. Eleven children were SPT positive to timothy, 10 to birch, 12 to dog, 11 to cat and 3 to house dust mite. Five of the asthmatic children were SPT negative. Twelve non-atopic children who did not have asthma or other atopic conditions were included as controls.

Circulating IgE to birch, timothy, cat, dog and Dermatophagoides pteronyssinus was analysed with UniCAPTM, according to recommendations of the manufacturer (Pharmacia Diagnostics, Uppsala, Sweden). Samples with IgE levels above $0.35 \mathrm{kU}_{\mathrm{A}} / \mathrm{ml}$ were regarded positive. The thirteen SPT positive children all had circulating IgE to one or several of the allergens, whereas none of the SPT negative children had detectable circulating $\operatorname{IgE}$ to the allergens tested.

\section{Ethics}

The study was approved by the Regional Ethics Committee for Human Research at the University Hospital of Linköping.

\section{Cell culture}

Venous blood was drawn into heparin treated tubes (Vacuette, Greiner Labor technik, Kremsmünster, Austria). PBMC were isolated on Ficoll Paque density 
gradient (Pharmacia Biotech, Sollentuna, Sweden) as described in detail elsewhere [20].

Aliquots of $1 \mathrm{ml}$, containing $1 \times 10^{6}$ cells, were cultured in AIM-V serum free medium (Life Technologies AB, Täby, Sweden) with $20 \mu \mathrm{M}$ mercaptoethanol (Sigma-Aldrich, Stockholm, Sweden). Optimal allergen doses and time points for cytokine secretion were determined in a pilot study including cells from six adults. Doses tested were 1 000, 10000 and 50000 standardised units/ml and time points tested were 24, 48, 72, 96, 144 and $192 \mathrm{~h}$. The cells were stimulated with birch, timothy, cat, dog and Dermatophagoides pteronyssinus allergen extracts from ALK at 10000 standardised units $/ \mathrm{ml}$. Separate cultures were performed with $2 \mu \mathrm{g} / \mathrm{ml}$ monoclonal antibodies to the IL-4 receptor (R\&D Systems, Abingdon, UK), enabling measurement of IL-4 [21]. Two $\mu \mathrm{g} / \mathrm{ml}$ of phytohaemagglutinin A (PHA) was used as a positive control. Background responses (cultures with medium only) were subtracted from the allergen and PHA induced responses. The cells were cultured at $37^{\circ} \mathrm{C}$ with $5 \% \mathrm{CO}_{2}$ (Forma $\mathrm{CO}_{2}$-incubator model 3862, Forma Scientific Inc., Marietta, Ohio, USA) for $144 \mathrm{~h}$. The supernatants were collected after centrifugation and stored at $-70^{\circ} \mathrm{C}$.

\section{Cytokine analyses}

The levels of IFN- $\gamma$, IL-4, IL-5, IL-9, IL-10 and IL-13 were determined by Enzyme-Linked Immunosorbent Assay (ELISA). Anti-human IL-9 monoclonal antibodies MH9A4 (IgG2b) and MH9A3 (IgG1) were derived from C57Bl/6 mice immunised with human IL-9 coupled to ovalbumin, as described 
previously for mouse IL-9 [9]. The MH9A3 antibodies were biotinylated using an EZ-Link ${ }^{\mathrm{TM}}$ Sulfo-NHS-LC-biotinylation kit (Pierce Chemical Co, Rockford, IL, USA), according to the protocol of the manufacturer. Costar 3690 plates (Corning Inc, Corning, NY, USA) were coated overnight at room temperature. The following mouse anti-human coating antibodies were used, diluted in carbonate buffer, $\mathrm{pH}$ 9.6; IL-4 and IFN- $\gamma$ (clone no 3010.211 and 2571.811, respectively, R\&D Systems, Abingdon, UK), IL-5 (clone no TRFK 5, PharMingen, San Diego, CA, USA), IL-9 (clone no MH9A4), IL-10 and IL-13 (coating antibody, PeliPair ${ }^{\mathrm{TM}}$ reagent set, CLB, Amsterdam, The Netherlands). The concentrations used were $2 \mu \mathrm{g} / \mathrm{ml}$ for IFN- $\gamma, 4 \mu \mathrm{g} / \mathrm{ml}$ for IL-4, $0.25 \mu \mathrm{g} / \mathrm{ml}$ for IL-5, $5 \mu \mathrm{g} / \mathrm{ml}$ for IL-9, and a 1:100 dilution for IL-10 and IL-13. Excess free antibodies were washed off (Wellwash Ascent, Labsystems, Stockholm, Sweden) with $4 \times 250 \mu 1$ PBS-Tween (0.05\% Tween 20 in PBS, pH 7.4), and the wells were incubated for $1 \mathrm{~h}$ at room temperature on a plate shaker (Thermostar, Labvision, Stockholm, Sweden) with $100 \mu 1 /$ well of low-fat milk to block non-specific protein binding sites.

The plates were washed as described above and $50 \mu 1$ of samples or standards; recombinant human IFN- - , IL-4 and IL-9 (R\&D Systems), IL-5 (PharMingen), IL10 and IL-13 (CLB) were added to duplicate wells. A control using AIM-V serum free medium with $20 \mu \mathrm{M}$ mercaptoethanol was also included. The plates were incubated and washed as before.

Biotinylated detection antibodies, goat anti-human IFN- $\gamma$ and IL-4 (R\&D Systems), rat anti-human IL-5 (clone no JES1-5A10, PharMingen), mouse anti- 
human IL-9 (clone no MH9A4), IL-10 and IL-13 (CLB), were then added (50 $\mu \mathrm{l} /$ well). All were diluted in high performance ELISA-dilution buffer (CLB), to the final concentrations of $0.20 \mu \mathrm{g} / \mathrm{ml}$ for IFN- $\gamma, 0.50 \mu \mathrm{g} / \mathrm{ml}$ for IL- $4,1 \mu \mathrm{g} / \mathrm{ml}$ for IL-5 and $90 \mathrm{ng} / \mathrm{ml}$ for IL-9. The antibodies to IL-10 and IL-13 were diluted 1:100. This was followed by another incubation and wash.

Streptavidin-poly horseradish peroxidase (50 $\mu \mathrm{l} /$ well, $0.1 \mu \mathrm{M}, \mathrm{CLB})$ was added, and the plates were incubated as before, but for 30 minutes, and then washed. Thereafter, 3,3',5,5'-tetramethylbenzidine (TMB) liquid substrate (SigmaAldrich) was added (50 $\mu \mathrm{l} /$ well), and incubated as before but for 30 minutes in the dark. $1.8 \mathrm{M} \mathrm{H}_{2} \mathrm{SO}_{4}(50 \mu \mathrm{l} /$ well) was finally added to stop the reaction. The amount of substrate converted to product was thereafter detected as optical densities (OD) at $450 \mathrm{~nm}$ in an Anthos ht II ELISA reader (Anthos ht II, Labdesign, Täby, Sweden). Values were expressed as $\mathrm{pg} / \mathrm{ml}$ deduced from the OD of the standard curve after subtracting the blanks. The sensitivity limits for quantitative determinations were $2 \mathrm{pg} / \mathrm{ml}$ for IL-10 and IL- $13,3 \mathrm{pg} / \mathrm{ml}$ for IL-5, $6 \mathrm{pg} / \mathrm{ml}$ for IL-4,10 pg/ml for IL-9 and $25 \mathrm{pg} / \mathrm{ml}$ for IFN- $\gamma$.

\section{Statistics}

As the cytokine levels were not normally distributed, even after logarithmic transformation, non-parametric tests, corrected for ties, were used. Comparisons between unpaired groups were analysed with Mann-Whitney Utest. The chi-square test was employed for categorical variables, and Fisher's exact test was used when the expected frequency for any cell was less than five. 
A p-value of $<0.05$ was considered as statistically significant. Calculations were performed with a statistical package, StatView 5.0 for Macintosh (Acabus Concepts Inc., Berkeley, CA, USA). 


\section{Results}

Detectable levels of IL-4 were more commonly observed in atopic asthmatics than in controls after dog and birch stimulation, with a similar trend after cat stimulation (Table 1). Furthermore, the cat, dog and birch induced levels of IL-4 were significantly higher in atopic asthmatics than in controls, with a similar trend after stimulation with timothy.

The IL-5 secretion was significantly higher in atopic asthmatics than in controls after stimulation with cat, dog and HDM. Furthermore, non-atopic asthmatics also tended to produce more IL-5 than controls after cat and dog stimulation (Table 2 and Fig $1 \mathrm{a}$ and b). Moreover, six atopic asthmatics, three non-atopic asthmatics but none of the control children had IL-5 levels above the median (of the whole group of children), both after cat and dog stimulation, whereas three atopic asthmatics, one non-atopic asthmatic and six control children had IL-5 levels below the median both after cat and dog stimulation (Fisher's exact test, $\mathrm{p}=0.03$ for atopic asthmatics vs controls and non-atopic asthmatics vs controls).

Interleukin-9 secretion was more commonly detected, and the levels were higher, in atopic asthmatics than in controls after dog stimulation (Table 3). A similar trend was observed after cat stimulation.

Atopic asthmatic and non-atopic asthmatic children produced similar amounts of IL-10, IL-13 and IFN- $\gamma$, as control children after allergen stimulation (data not 
shown). The cat induced IL-10 secretion was significantly higher in non-atopic asthmatic than in atopic asthmatic children, however (Fig 2). 


\section{Discussion}

Both non-atopic and atopic asthmatic children more often produced detectable levels of IL-5 after cat and dog allergen stimulation than control children. Our results support and extend previous studies in adults, showing that both atopic and non-atopic asthma are associated with high levels of IL-5 in bronchial biopsies [12,14] and bronchoalveolar lavage [15]. Interleukin-5 causes allergic inflammation by its eosinophil activating properties [5]. High numbers of eosinophils are found in the bronchial submucosa [13] and bronchoalveolar lavage [15] of both atopic and non-atopic asthmatics. Our results support the hypothesis that non-atopic asthma is caused by an allergen-induced inflammation with eosinophils without the production of IgE. As IL-4 and IL-5 are differentially regulated [16-18], eosinophil mediated inflammation in the absence of IgE may be possible. Although the size of the group of non-atopic asthmatic children is small, and we cannot exclude that the lack of differences in the levels of other Th2 cytokines than IL-5 after allergen stimulation is due to a type II error, our findings suggest that IL-5 is the cytokine most strongly connected to non-atopic asthma. As immunotherapy reduces IL-5 expression [22], it is tempting to speculate that also non-atopic asthmatic children could benefit from such treatment. That high levels of IL-5 were noted after cat and dog allergen stimulation, but not after stimulation with house dust mite or seasonal allergens, could be due to the high and continuous exposure to cat and dog allergens in Sweden [23]. Due to the Swedish climate, house dust mite allergen exposure is low [23]. 
Children with atopic asthma, but not non-atopic asthma, produced higher levels of IL-4 after allergen stimulation than control children did. These results are consistent with several other studies, where this IgE-inducing cytokine was strongly connected with sensitisation [24-28].

Children with atopic asthma also produced high levels of IL-9. This cytokine has IgE-inducing properties and also stimulates T-cell, mast cell and eosinophil proliferation [6-9]. Increased IL-9 mRNA expression [26] and secretion [28] after allergen stimulation have previously been associated with atopic disease. The similar IL-13 secretion in the different groups of children may be due to the fact that IL-13 expression is less tightly regulated than IL-4 production, and not restricted to Th2 cells [29].

Interleukin-10 reduces IgE production, prevents eosinophil survival and has anti-inflammatory properties [10]. In this study non-atopic asthmatics produced more IL-10 than atopic asthmatics after cat stimulation. An inverse relationship between skin prick test positivity and IL-10 production has previously been reported in children with atopic symptoms $[26,28]$.

In conclusion, high levels of eosinophilia-associated IL-5 responses are induced by cat and dog allergen in both atopic and non-atopic asthmatic children. The Th2 cytokines IL-4 and IL-9 were associated only with atopic asthma, probably due to their IgE-inducing properties. 


\section{Acknowledgements}

We thank Prof Bengt Björkstén, Centre for Allergy Research, Sweden, for helpful discussion, Dr Jacques van Snick, Ludwig Institute for Cancer Research, Brussels Branch, Belgium for kindly providing antibodies to IL-9, and Ulrika Bengtsson, Anne-Marie Fornander, Lena Lindell, Ing-Marie Sandberg, and Kristina Warstedt, Department of Health and Environment, Division of Paediatrics, Linköping University Hospital, Sweden, for excellent technical assistance. Dr Lennart Bråbäck, Mid Sweden Research and Development Centre, Sundsvall Hospital, Prof Bengt Björkstén and Prof Max Kjellman, Division of Paediatrics, Linköping University Hospital, are acknowledged for organising the Linköping part of the ISAAC phase II study.

The Swedish Medical Research Council (grant \#7510), The Swedish Foundation for Health and Care Sciences and Allergy Research, The National Heart and Lung Association and Glaxo-Wellcome to Prof Bengt Björkstén, The National Swedish Association against Allergic Diseases, and Linköping University are acknowledged for financial support. 
Table 1. Interleukin-4 secretion after allergen stimulation (frequency, $i e(\%)$ of samples with detectable levels and median (range) $(\mathrm{pg} / \mathrm{ml})$ in samples with detectable levels).

The proportion of children with detectable IL-4 secretion among the atopic and nonatopic asthmatics was compared with the proportion in the controls with Fisher's exact test. The IL-4 levels in atopic and non-atopic asthmatics were compared with the levels in controls with Mann-Whitney U-test. ${ }^{\circ} \mathrm{p}=0.07,{ }^{*} \mathrm{p}<0.05,{ }^{* *} \mathrm{p}<0.01$.

\begin{tabular}{|c|c|c|c|c|c|}
\hline Diagnosis & Cat & Dog & Birch & Timothy & HDM \\
\hline $\begin{array}{c}\text { Atopic asthma } \\
\mathrm{n}=13\end{array}$ & $46 \%^{\mathbf{0}}$ & $46 \%^{*}$ & $31^{*}$ & $62 \%$ & $8 \%$ \\
\hline $\begin{array}{c}\text { Non-atopic asthma } \\
\mathrm{n}=5\end{array}$ & $0 \%$ & $0 \%$ & $20 \%$ & $20 \%$ & $0 \%$ \\
\hline $\begin{array}{c}\text { Controls } \\
\mathrm{n}=12\end{array}$ & $8 \%$ & $0 \%$ & $0 \%$ & $10 \%$ & $8 \%$ \\
\hline
\end{tabular}


Table 2. Interleukin-5 secretion after allergen stimulation (frequency, $i e(\%)$ of samples with detectable levels and median (range) $(\mathrm{pg} / \mathrm{ml})$ in samples with detectable levels).

The proportion of children with detectable IL-5 secretion among the atopic and nonatopic asthmatics was compared with the proportion in the controls with Fisher's exact test. The IL-5 levels in atopic and non-atopic asthmatics were compared with the levels in controls with Mann-Whitney $U$-test. ${ }^{\circ} \mathrm{p}=0.06{ }^{*}{ }^{*} \mathrm{p}<0.05$.

\begin{tabular}{|c|c|c|c|c|c|}
\hline Diagnosis & Cat & Dog & Birch & Timothy & HDM \\
\hline $\begin{array}{c}\text { Atopic asthma } \\
\mathrm{n}=13\end{array}$ & $100 \%$ & $92 \%$ & $31 \%$ & $69 \%$ & $54 \%$ \\
\cline { 2 - 6 } & $25(6-144)^{*}$ & $16(7-37)^{*}$ & $19(7-218)$ & $14(4-645)$ & $10(3-56)^{*}$ \\
\hline $\begin{array}{c}\text { Non-atopic asthma } \\
\mathrm{n}=5\end{array}$ & $100 \%$ & $100 \%$ & $20 \%$ & $20 \%$ & $40 \%$ \\
\hline $\begin{array}{c}\text { Controls } \\
\mathrm{n}=12\end{array}$ & $22(8-72)^{\mathbf{o}}$ & $28(5-78)^{\mathbf{o}}$ & 32 & 93 & $16(4-29)$ \\
\hline & $14 \%$ & $67 \%$ & $17 \%$ & $33 \%$ & $17 \%$ \\
\hline
\end{tabular}


Table 3. Interleukin-9 secretion after allergen stimulation (frequency, $i e(\%)$ of samples with detectable levels and median (range) $(\mathrm{pg} / \mathrm{ml})$ in samples with detectable levels).

The proportion of children with detectable IL-9 secretion among the atopic and nonatopic asthmatics was compared with the proportion in the controls with Fisher's exact test. The IL-9 levels in atopic and non-atopic asthmatics were compared with the levels in controls with Mann-Whitney $U$-test. ${ }^{\mathbf{o}} \mathrm{p}=0.08,{ }^{*} \mathrm{p}<0.05$.

\begin{tabular}{|c|c|c|c|c|c|}
\hline Diagnosis & Cat & Dog & Birch & Timothy & HDM \\
\hline $\begin{array}{c}\text { Atopic asthma } \\
\mathrm{n}=13\end{array}$ & $69 \%$ & $69 \%^{*}$ & $8 \%$ & $15 \%$ & $54 \%$ \\
\cline { 2 - 6 }$\left(\begin{array}{c}122 \\
(70-264)^{\mathbf{o}}\end{array}\right.$ & $\begin{array}{c}264 \\
(99-726)^{*}\end{array}$ & 31 & $\begin{array}{c}160 \\
(158-161)\end{array}$ & $\begin{array}{c}84 \\
(31-164)\end{array}$ \\
\hline $\begin{array}{c}\text { Non-atopic asthma } \\
\mathrm{n}=5\end{array}$ & $80 \%$ & $60 \%$ & $20 \%$ & $20 \%$ & $20 \%$ \\
\cline { 2 - 6 } & $\begin{array}{c}98 \\
(34-192)\end{array}$ & $\begin{array}{c}114 \\
(61-145)\end{array}$ & 149 & 248 & 97 \\
\hline $\begin{array}{c}\text { Controls } \\
\mathrm{n}=12\end{array}$ & $\begin{array}{c}50 \% \\
(27-195)\end{array}$ & $\begin{array}{c}15 \\
(5-24)\end{array}$ & $0 \%$ & $17 \%$ & $8 \%$ \\
\cline { 2 - 6 } & & & 74 & 118 \\
\hline
\end{tabular}




\section{Legends to figures}

Fig 1. Cat (a) and $\operatorname{dog}(\mathrm{b})$ induced IL-5 secretion ( $\mathrm{pg} / \mathrm{ml})$ in atopic asthmatic, non-atopic asthmatic and control children. $1 \times 10^{6} \mathrm{PBMC} / \mathrm{ml}$ were cultured for $144 \mathrm{~h}$ with cat (a) and dog (b) allergen extract in AIM-V serum free medium supplemented with $20 \mu \mathrm{M}$ mercaptoethanol. Interleukin-5 levels in the supernatants were measured with ELISA, and background responses (cultures with medium only) were subtracted. The lines indicate median values. Filled circles indicate sensitisation to cat (a) and dog (b). The IL-5 levels in atopic and nonatopic asthmatic children were compared with the levels in control children with Mann-Whitney U-test.

Fig 2. Cat (induced IL-10 secretion $(\mathrm{pg} / \mathrm{ml})$ in atopic asthmatic, non-atopic asthmatic and control children. $1 \times 10^{6} \mathrm{PBMC} / \mathrm{ml}$ were cultured for $144 \mathrm{~h}$ with cat allergen extract in AIM-V serum free medium supplemented with $20 \mu \mathrm{M}$ mercaptoethanol. Interleukin-10 levels in the supernatants were measured with ELISA, and background responses (cultures with medium only) were subtracted. The lines indicate median values. Filled circles indicate sensitisation to cat. The IL-10 levels in atopic and nonatopic asthmatic children were compared with Mann-Whitney $U$-test. 


\section{References}

1. Robinson DS, Hamid Q, Ying S, et al. Predominant Th2-like bronchoalveolar Tlymphocyte population in atopic asthma. N Engl J Med 1992;326:298-304.

2. Kay AB. Allergy and allergic diseases - First of two parts. N Engl J Med 2001;344:30-37.

3. Pène J, Rousset F, Brière F, et al. IgE production by normal human lymphocytes is induced by interleukin 4 and suppressed by interferons $\gamma$ and $\alpha$ and prostaglandin $E_{2}$. Proc Natl Acad Sci USA 1988;85:6880-6884.

4. Punnonen J, Aversa G, Cocks BG, et al. Interleukin 13 induces interleukin 4-independent $\mathrm{IgG}_{4}$ and $\mathrm{IgE}$ synthesis and CD23 expression by human B cells. Proc Natl Acad Sci USA 1993;90:3730-3734.

5. Gleich GJ. Mechanisms of eosinophil-associated inflammation. J Allergy Clin Immunol 2000;105:651-663.

6. Levitt RC, McLane MP, MacDonald D, et al. IL-9 pathway in asthma: New therapeutic targets for allergic inflammatory disorders. J Allergy Clin Immunol 1999;103:S485-S491.

7. Dugas B, Renauld JC, Pène J, et al. Interleukin-9 potentiates the interleukin-4 induced immunoglobulin (IgG, IgM and IgE) production by normal human B lymphocytes. Eur J Immunol 1993;23:1687-1692.

8. Renauld JC, Louahed J, Vink A, Van Snick J, Uyttenhove C. Interleukin-9. Adv Immunol 1993;54:79-97.

9. Richard M, Grencis RK, Humphreys NE, Renauld JC, Van Snick J. Anti-IL-9 vaccination prevents worm expulsion and blood eosinophilia in Trichuris muris-infected mice. Proc Natl Acad Sci USA 2000;97:767-772.

10. Koulis A, Robinson DS. The anti-inflammatory effects of interleukin-10 in allergic disease. Clin Exp Allergy 2000;30:747-750.

11. Punnonen J, de Waal Malefyt R, van Vlasselaer P, Gauchat JF, de Vries JE. IL-10 and viral IL-10 prevent IL-4-induced IgE synthesis by inhibiting accessory cell function of monocytes. J Immunol 1993;151:1280-1289.

12. Humbert M, Corrigan CJ, Kimmitt P, Till SJ, Kay AB, Durham SR. Relationship between IL-4 and IL-5 mRNA expression and disease severity in atopic asthma. Am J Respir Crit Care Med 1997;156:704-708.

13. Ying S, Meng Q, Zeibecoglou $\mathrm{K}$, et al. Eosinophil chemotactic chemokines (eotaxin, eotaxin-2, RANTES, monocyte chemoattractant protein-3 (MCP-3), and MCP-4), and C-C chemokine receptor 3 expression in bronchial biopsies from atopic and nonatopic (intrinsic) asthmatics. J Immunol 1999;163:6321-6329.

14. Humbert M, Menz G, Ying S, et al. The immunopathology of extrinsic (atopic) and intrinsic (non-atopic) asthma: More similarities than differences. Immunol Today 1999;20:528-533.

15. Walker C, Bode E, Boer L, Hansel TT, Blase K, Virchow JC. Allergic and nonallergic asthmatics have distinct patterns of $\mathrm{T}$ cell activation and cytokine production in peripheral blood and bronchoalveolar lavage. Am Rev Respir Dis 1992;146:109-115.

16. Zhang DH, Yang LY, Ray A. Differential responsiveness of the IL-5 and IL-4 genes to transcription factor GATA-3. J Immunol 1998;161:3817-3821. 
17. Mori A, Kaminuma O, Mikami T, et al. Transcriptional control of the IL-5 gene by human helper T cells: IL-5 synthesis is regulated independently from IL-2 or IL-4 synthesis. J Allergy Clin Immunol 1999;103:S429-S436.

18. Karulin AY, Hesse MD, Tary-Lehmann M, Lehmann PV. Single-cytokine-producing CD4 memory cells predominate in type 1 and type 2 immunity. J Immunol 2000;164:1862-1872.

19. Annus T, Björkstén B, Mai XM, et al. Wheezing in relation to atopy and environmental factors in Estonian and Swedish schoolchildren. Clin Exp Allergy 2001;31:1846-1853.

20. Jenmalm MC, Björkstén B, Macaubas C, Holt BJ, Smallacombe TB, Holt PG. Allergen induced cytokine secretion in relation to atopic symptoms and IgE and IgG subclass antibody responses. Pediatr Allergy Immunol 1999;10:168-174.

21. Bullens DMA, Rafiq K, Kasran A, Van Gool SW, Ceuppens JL. Naive human T cells can be a source of IL-4 during primary immune responses. Clin Exp Immunol 1999;118:384-391.

22. Wilson DR, Nouri-Ara KT, Walker SM, et al. Grass pollen immunotherapy: Symptomatic improvement correlates with reductions in eosinophils and IL-5 mRNA expression in the nasal mucosa during the pollen season. J Allergy Clin Immunol 2001;107:971-976.

23. Munir AKM, Einarsson R, Kjellman NIM, Björkstén B. Mite (Der p 1, Der f 1), cat (Fel d 1) and $\operatorname{dog}($ Can $\mathrm{f} 1$ ) allergens in the homes of babies with a family history of allergy. Allergy 1993;48:158-163.

24. Imada M, Estelle F, Simons R, Jay FT, HayGlass KT. Allergen-stimulated interleukin-4 and interferon- $\gamma$ production in primary culture: Responses of subjects with allergic rhinitis and normal controls. Immunology 1995;85:373-380.

25. Gabrielsson S, Paulie S, Rak S, et al. Specific induction of interleukin-4-producing cells in response to in vitro allergen stimulation in atopic individuals. Clin Exp Allergy 1997;27:808-815.

26. Macaubas C, Sly PD, Burton $\mathrm{P}$, et al. Regulation of Th-cell responses to inhalant allergen during early childhood. Clin Exp Allergy 1999;29:1223-1231.

27. Kimura M, Tsuruta S, Yoshida T. IL-4 production by PBMCs on stimulation with mite allergen is correlated with the level of serum $\operatorname{IgE}$ antibody against mite in children with bronchial asthma. J Allergy Clin Immunol 2000;105:327-332.

28. Jenmalm MC, Van Snick J, Cormont F, Salman B. Allergen-induced Th1 and Th2 cytokine secretion in relation to specific allergen sensitisation and atopic symptoms in children. Clin Exp Allergy 2001;31:1528-1535.

29. Essayan DM, Han WF, Li XM, Xiao HQ, Kleine-Tebbe J, Huang SK. Clonal diversity of IL4 and IL-13 expression in human allergen-specific T lymphocytes. J Allergy Clin Immunol 1996;98:1035-1044. 
Fig 1

a)

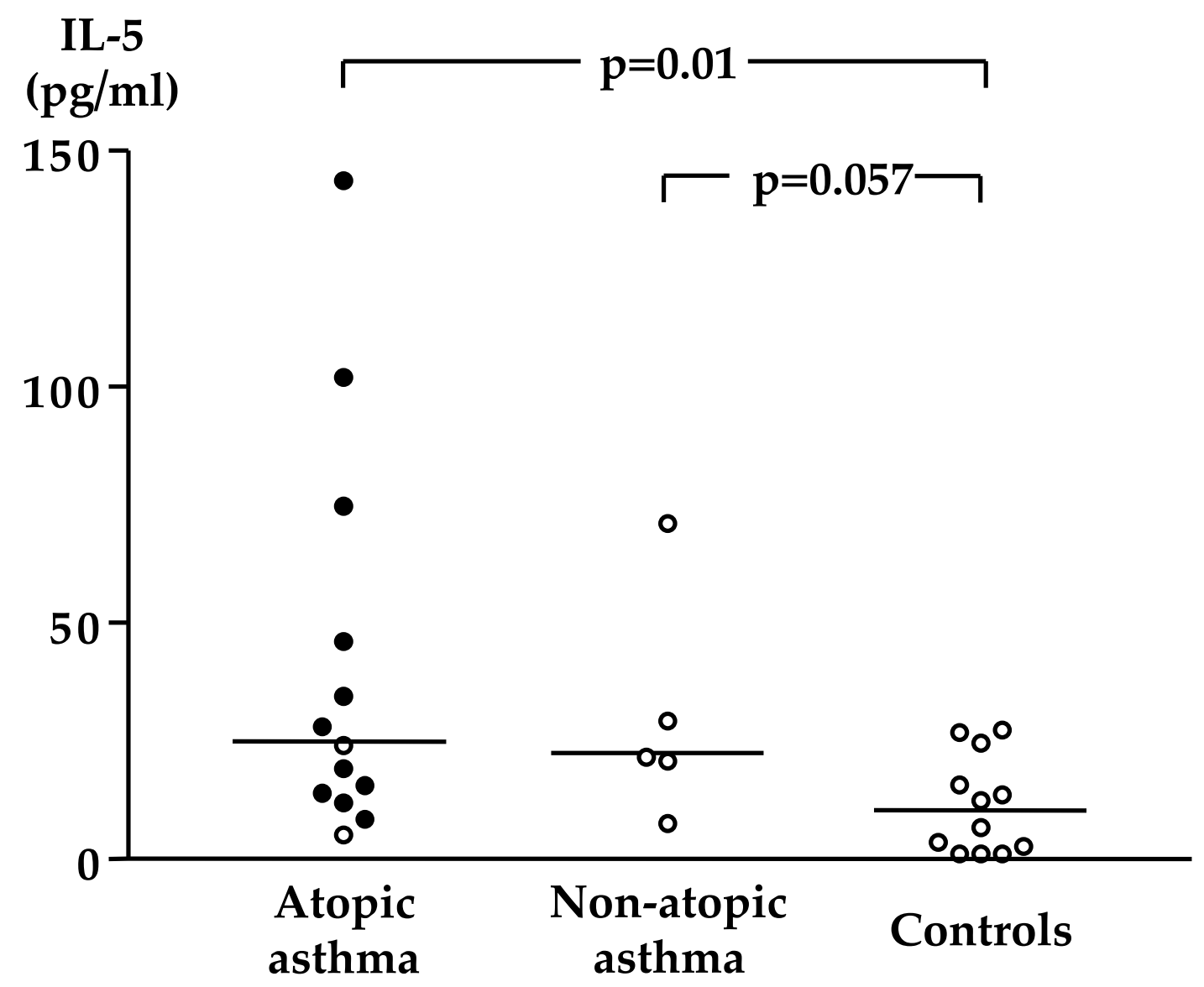

b)

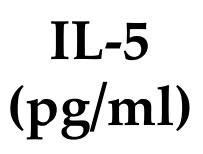

100

1007

75

50 $p<0.05$

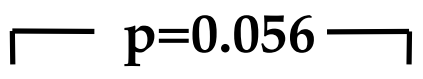

0

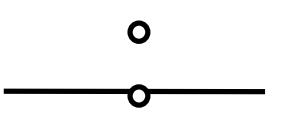

$25-\stackrel{0.0}{-\infty, 000}$

$\bullet$

0

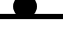

Atopic

asthma

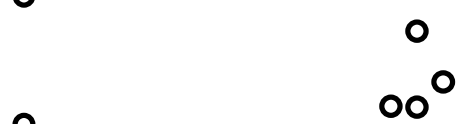

0

0

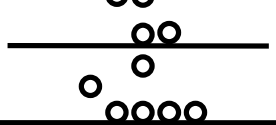

Controls 
Fig 2

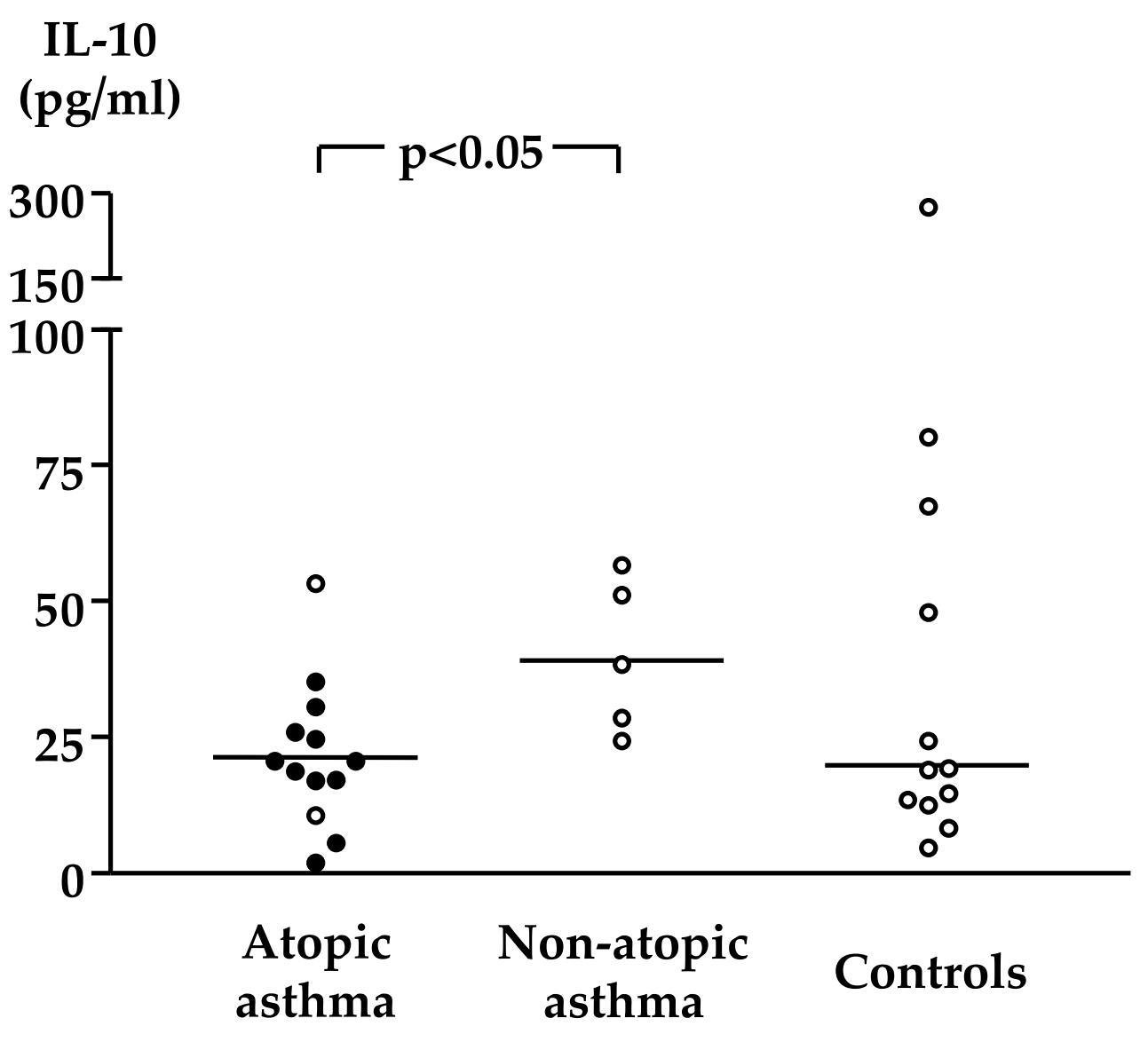

